\title{
Description of Proyseria petterae n. sp., with an amended generic diagnosis and a review of the species of Proyseria Petter, 1959 and Stegophorus Wehr, 1934 (Nematoda: Acuariidae)
}

\author{
Yasen Mutafchiev $\cdot$ Jean Mariaux $•$ \\ Boyko B. Georgiev
}

Received: 3 June 2014 / Accepted: 21 June 2014

(C) Springer Science+Business Media Dordrecht 2014

\begin{abstract}
Proyseria decora (Dujardin, 1845) (the type-species of the genus Proyseria Petter, 1959) is redescribed on the basis of specimens from Alcedo atthis (L.) (Coraciiformes: Alcedinidae) from Iran. $P$. petterae n. sp. is described from Corythornis vintsioides (Eydoux \& Gervais) (Alcedinidae) from Madagascar by light and scanning electron microscopy. Proyseria sp. from Alcedo euryzona Temminck from continental Malaysia is described on the basis of a single male specimen. Stegophorus alcedonis Puqin, Yanyin \& Guocal, 1991 from A. atthis in China is transferred to the genus Proyseria as P. alcedonis n. comb. The generic diagnosis of Proyseria is amended. Review of the species of the genera Proyseria and Stegophorus Wehr, 1934 is presented.
\end{abstract}

Y. Mutafchiev $(\bowtie) \cdot$ J. Mariaux

Natural History Museum of Geneva, 1 Route de

Malagnou, 1211 Geneva 6, Switzerland

e-mail: mutafchiev@gmail.com

Y. Mutafchiev $\cdot$ J. Mariaux

Department of Genetics and Evolution, University of Geneva, Boulevard d'Yvoy 4, 1205 Geneva, Switzerland

Y. Mutafchiev · B. B. Georgiev

Institute of Biodiversity and Ecosystem Research, Bulgarian Academy of Sciences, 2 Gagarin Street, 1113 Sofia, Bulgaria

\section{Introduction}

The genus Proyseria Petter, 1959 was erected as monotypic for Proyseria decora (Dujardin, 1845) (=Dispharagus decorus Dujardin, 1845), a parasite of common kingfisher, Alcedo atthis (L.) and then known from France and Iran (Dujardin, 1845; Chabaud 1953; Petter, 1959). Subsequently, it was reported from the same host in the Russian Far East (Oshmarin, 1963) and Vietnam (Ryzhikov \& Khokhlova, 1964). Our recent surveys of helminth parasites of kingfishers from Malaysia and Madagascar have revealed that the genus Proyseria is more diverse and has a wider geographical range than previously known.

The aim of the present study is to describe newlycollected specimens of Proyseria from Malaysia and Madagascar. In addition, we review the species of the related genus Stegophorus Wehr, 1934 and propose an amended generic diagnosis of Proyseria.

\section{Materials and methods}

During field trips by two of the present authors (JM and BBG), three Alcedo euryzona Temminck (Coraciiformes: Alcedinidae) in Selangor, Malaysia (10 August 2010) and two Corythornis vintsioides (Eydoux \& Gervais) (Coraciiformes: Alcedinidae) at Sahambaky, Madagascar (22-23 October 2013) were captured by mist nets and dissected immediately after their death. Nematodes collected under the koilin lining of the 
gizzard were fixed and stored in $70 \%$ ethanol. Voucher material of Proyseria decora (Dujardin, 1845) studied by Chabaud (1953) and Petter (1959) from the collections of the Muséum National d'Histoire Naturelle, Paris (MNHN), no. 527A, was re-examined.

For light-microscopical observations, specimens were cleared and examined as temporary mounts in lactophenol. A single female specimen from C. vintsioides used for scanning electron microscopy (SEM) observations was dehydrated in an ethanol series, immersed in hexamethyldisilazane for $20 \mathrm{~min}$, airdried, coated with gold in a Cressington 108-Auto coater and examined using a Zeiss DSM 940A microscope at $10 \mathrm{kV}$. All measurements are in micrometres unless otherwise stated. Metrical data are given as the range, with the mean and the number of measurements taken (n) in parentheses unless otherwise indicated. The following indices were used: $\mathrm{I}_{\mathrm{mOE} / \mathrm{gOE}}$, length of muscular oesophagus/length of glandular oesophagus; $\mathrm{I}_{\mathrm{OE} / \mathrm{BL}}$, length of oesophagus/body length; $\mathrm{I}_{\mathrm{LSP} / \mathrm{RSP} \text {, }}$ length of left spicule/length of right spicule.

DNA was extracted from mid-body portion of a single female specimen, whose body extremities were used for SEM study, and dissolved in $100 \mu \mathrm{TE}$ buffer. A fragment of the mitochondrial cytochrome $c$ oxidase subunit I (COI) gene was amplified using a reverse primer 5'-AAT AAG TAC GAG TAT CAA TAT C- ${ }^{\prime}$ (Casiraghi et al., 2001) and forward primer 5'-TGA TTG GTG GTT TTG GTA ATT G-3' from the same study, elongated with three nucleotides at the $3^{\prime}$-end. PCR reaction was performed in a final volume of $50 \mu \mathrm{l}$ containing $1 \times$ CoralLoad PCR buffer (Qiagen), 0.2 $\mathrm{mM}$ of each dNTP, 10 pmol of each primer, $1.5 \mathrm{U}$ Taq polymerase (Qiagen) and $1 \mu \mathrm{l}$ of DNA extract. The PCR cycling conditions were: $94^{\circ} \mathrm{C}$ for $1 \mathrm{~min}$ followed by 5 cycles $\left(94^{\circ} \mathrm{C}\right.$ for $50 \mathrm{~s}, 47^{\circ} \mathrm{C}$ for $50 \mathrm{~s}$ and $72^{\circ}$ for 60 s), followed by 30 cycles $\left(94^{\circ}\right.$ for $50 \mathrm{~s}, 50^{\circ}$ for $50 \mathrm{~s}, 72^{\circ}$ for $60 \mathrm{~s}$ ), followed by a final extension step at $72^{\circ} \mathrm{C}$ for $5 \mathrm{~min}$. Sequencing was performed by Macrogen Inc. using the amplification primers.

The newly-collected materials described in this study are deposited in the Natural History Museum of Geneva (MHNG).

\section{Proyseria petterae n. sp.}

Type-host: Corythornis vintsioides (Eydoux \& Gervais) (Coraciiformes: Alcedinidae).
Type-locality: Sahambaky, Madagascar (19 $3^{\prime} 54^{\prime \prime} \mathrm{S}$, $48^{\circ} 20^{\prime} 25^{\prime \prime} \mathrm{E}$ ).

Site in host: Under the koilin lining of the gizzard.

Prevalence: In two out of two host individuals studied. Intensity of infection: 1-3 (mean 2).

Type-specimens: Holotype: MHNG-INVE-87381 (1 male). Paratypes: MHNG-INVE-87382 (2 females); MHNG-INVE-87384 (anterior and posterior fragments of 1 female, SEM stub).

Etymology: The new species is named for Dr A. Petter, Muséum National d'Histoire Naturelle, Paris, in recognition of her contribution to the taxonomy of this nematode group.

Description (Figs. 1, 2)

General. Small-sized acuariid nematodes with thin body. Anterior end with 2 pseudolabia, each of them with prominent apex and bearing single amphid and pair of inconspicuous cephalic papillae (Figs. 1A, B, 2A). Cuticular ornamentation present in form of denticulate collarette formed by 2 halves, each of them posterior to pseudolabium (Figs. 1A, B, 2A). Sublabia differentiated between pseudolabia (Figs. 1B2, 2B). Body cuticle thick, with distinct transverse striations interrupted along lateral body line. Deirids large, bicuspid, situated at level anterior to junction of buccal cavity and muscular oesophagus. Postdeirids bifurcate, each situated in shallow pit (Fig. 1C). Buccal cavity long, with conspicuous cross-striations. Muscular and glandular portions of oesophagus distinct. Glandular oesophagus and intestine with similar width at their junction. Nerve-ring surrounds anterior portion of muscular oesophagus. Excretory pore posterior to nerve-ring (Fig. 1A). Phasmids subterminal (Figs. 1E, G, 2D).

Male $(\mathrm{n}=1)$. Body $4.35 \mathrm{~mm}$ long. Maximum body width 125 at mid-length, 65 at level of cloaca. Tail 133 long. Cuticle 6 thick, with transverse striations 7-8 apart. Collarette 31 long, 41 wide in lateral view, each half bears 56 cusps, c. 3 long. Deirids 18 long, 18 wide, situated at 104 from anterior extremity. Left and right postdeirids situated at $0.58 \mathrm{~mm}$ and $1.33 \mathrm{~mm}$, respectively, from posterior extremity. Excretory pore at 219 from anterior extremity. Buccal cavity 135 long, 8 wide. Muscular oesophagus 685 long, 33 wide at mid-length, with maximum width 36 at posterior end. Glandular oesophagus 1,482, with maximum 

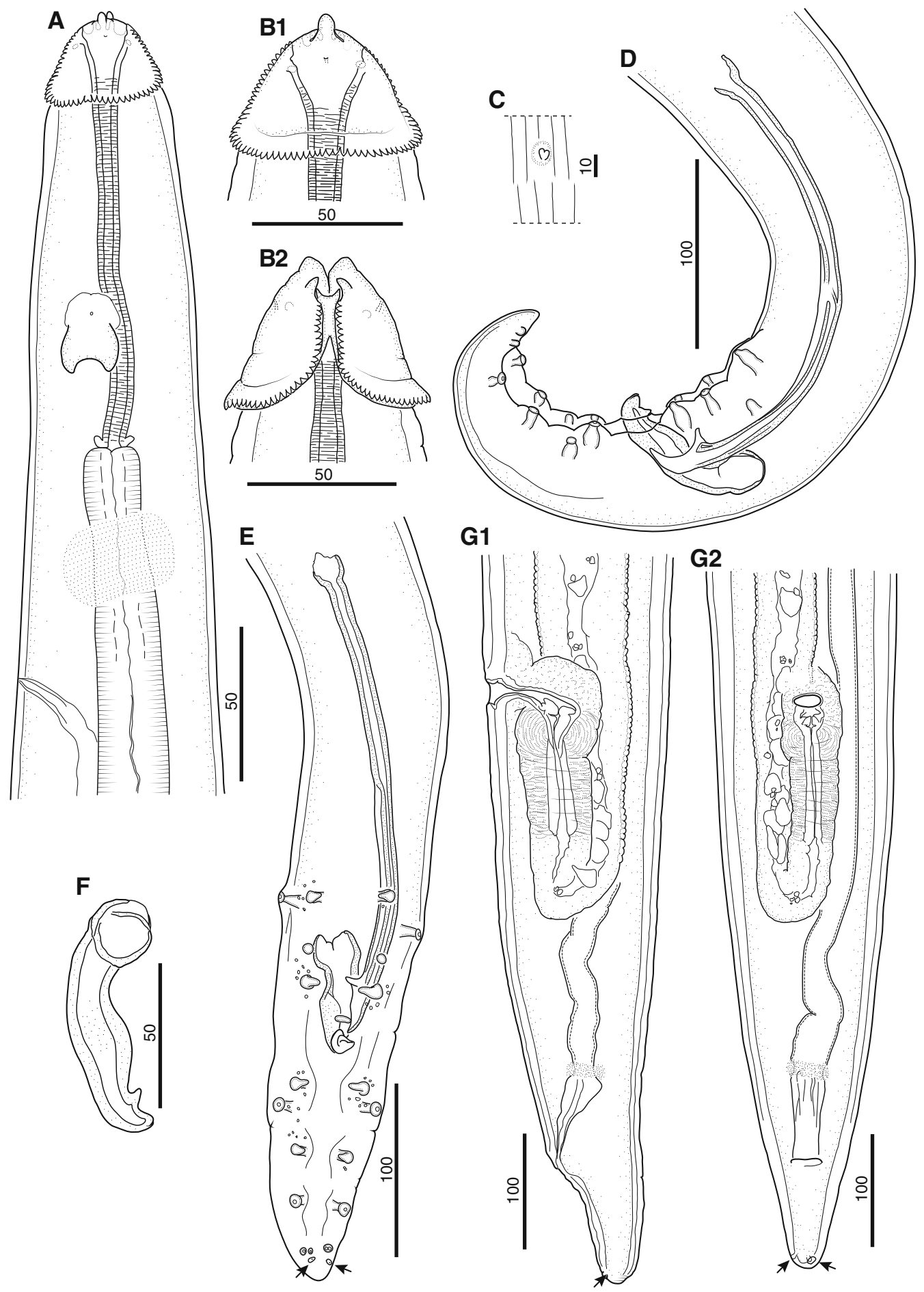

G2

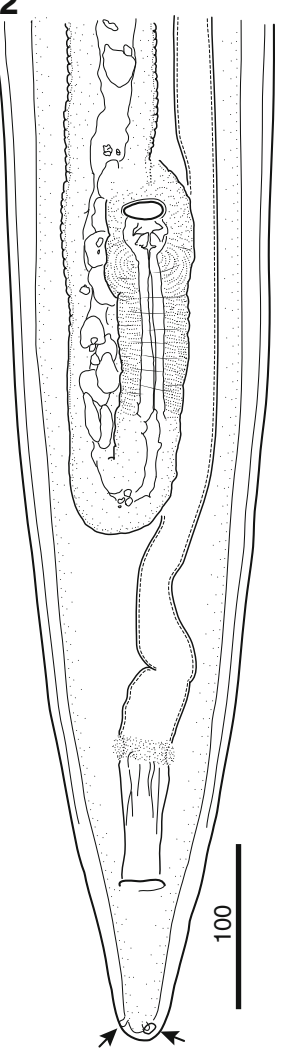

Fig. 1 Proyseria petterae n. sp. A, Anterior end, male, lateral view; B, Cephalic region, female, lateral (B1) and dorsoventral (B2) view; C, Postdeirid, female; D, Posterior end, male, sinistral view; E, Posterior end, male, ventral view, note phasmids (arrows); F, Right spicule, dextral view; G, Posterior extremity, female, sinistral (G1) and ventral (G2) view, note phasmids (arrows). Scale-bars are in micrometres 

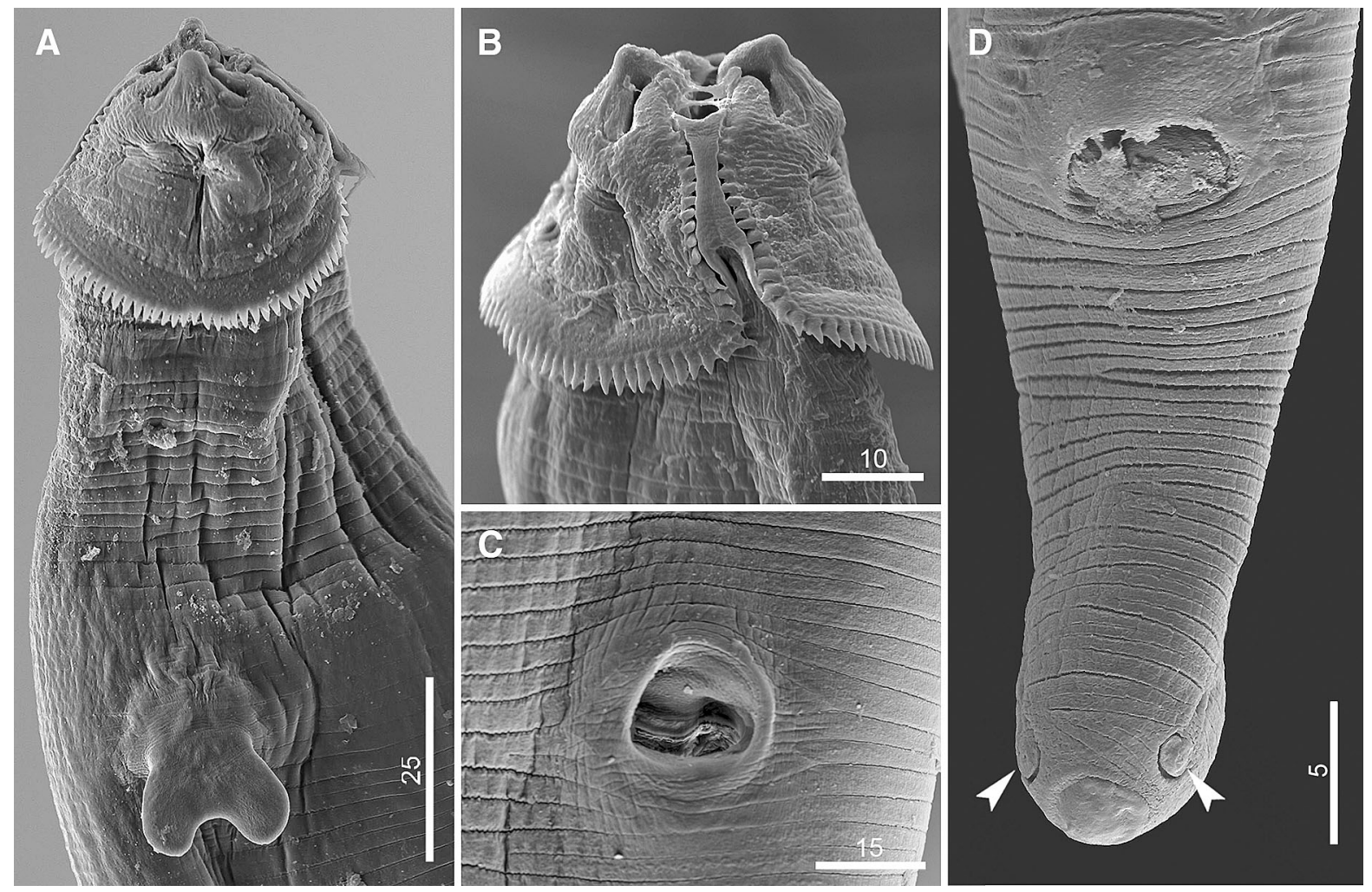

Fig. 2 Proyseria petterae n. sp., female, scanning electron micrographs. A, Anterior end, lateral view; B, Cephalic region, dorsoventral view; C, Vulva; D, Posterior end, ventral view, note phasmids (arrowheads). Scale-bars are in micrometres

width at mid-length 77 . Nerve-ring at 165 from anterior body end. Testis reflection at $2.28 \mathrm{~mm}$ from anterior end. Caudal alae slightly developed, 251 long (Fig. 1D, E). Precloacal papillae represented by single ventral precloacal papilla and 4 pairs of pedunculate papillae: pairs 1, 3 and 4 subventral, pair 2 displaced in lateral direction. Postcloacal papillae 6 pairs: 5 subventral pedunculate pairs and 1 pair of small papillae situated between bases of last pair of subventral papillae. Left spicule 289 long, composed of handle, 146 long, and blade, 143 long (Fig. 1E). Right spicule robust, 92 long, with 2 prominent distal cusps (Fig. 1F).

Female $(\mathrm{n}=2$; measurements of one of specimens are followed by those of the second one in parentheses). Body 8.27 (8.35) $\mathrm{mm}$ long, with maximum body width at mid-body, 188 (247); body width at level of vulva 155 (197), at level of anus 73 (80). Collarette 46 (48) long, 65 (68) wide in lateral view, each half bears 70-72 cusps, 4-5 long. Deirids 24-26 long, 28-29 wide situated at 147 (155) from anterior extremity. Left and right postdeirids situated at $2.10(2.33) \mathrm{mm}$ and $2.73(3.26) \mathrm{mm}$, respectively, from posterior extremity. Excretory pore at 297 (309) from anterior extremity. Buccal cavity 172 (188) long, 10-12 wide. Muscular oesophagus 1,013 (961) long, 42 (43) wide at mid-length and 59 (54) at its posterior end. Glandular oesophagus 2,140 (2,246) long, with maximum width at mid-length 93 (90). Cuticle 22-23 thick, with transverse striations, 6 apart. Vulva (Figs. 1G, 2C) at 498 (499) from posterior extremity. Vagina directed posteriorly, composed of vagina vera, 74 (74) long, separated by sphincter from vagina uterina, 101 (104) long, with thick muscular walls. Reproductive system monodelphic. Tail 105 (107) long, with rounded tip (Figs. 1G, 2D).

Molecular identification. A fragment of $646 \mathrm{bp}$ of the COI gene was amplified. The nucleotide sequence is available in the GenBank database (KJ995862). 


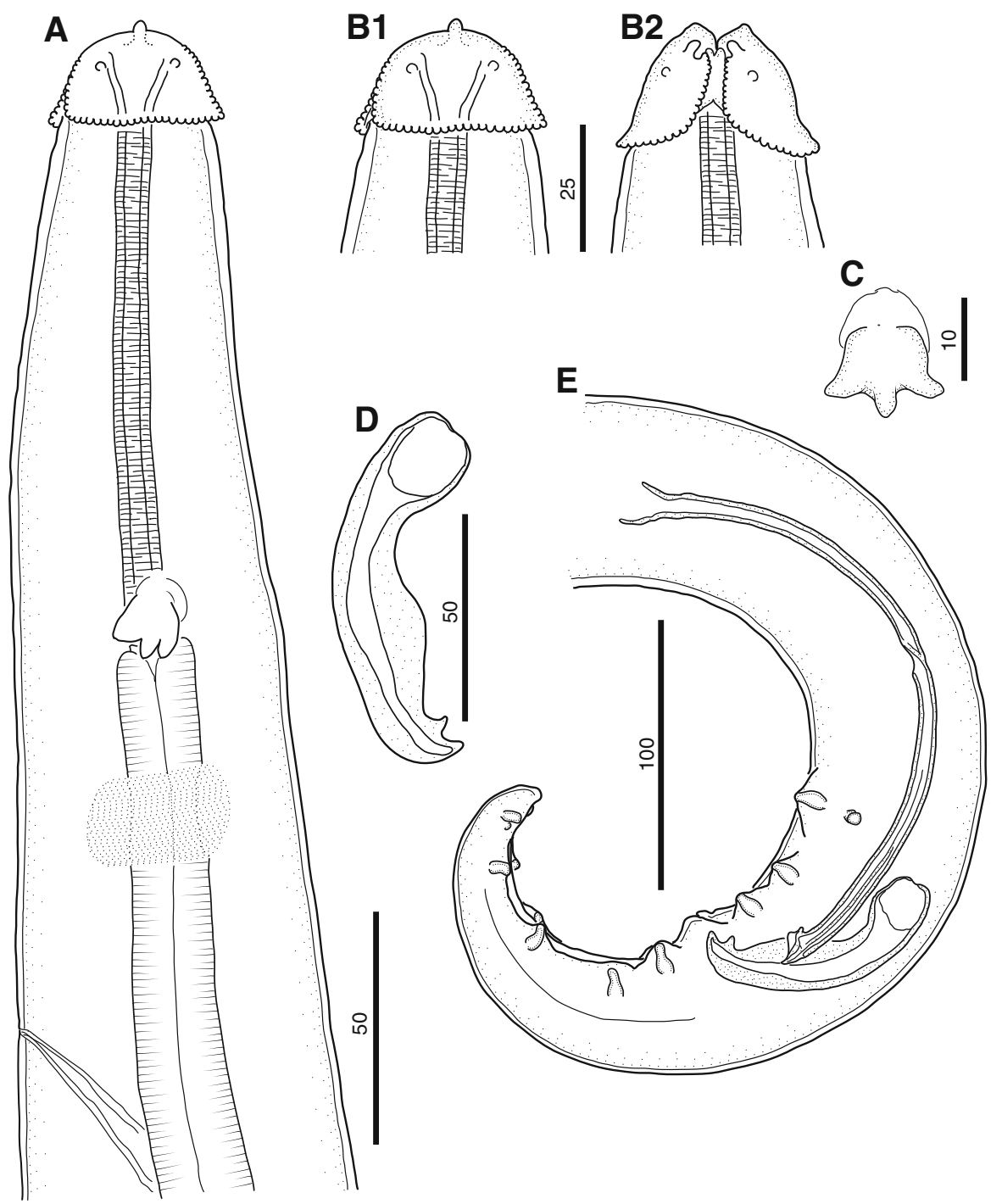

Fig. 3 Proyseria decora, male. A, Anterior end, male, lateral view; B, Cephalic region, lateral (B1) and dorsoventral (B2) view; C, Deirid; D, Right spicule, dextral view; E, Posterior end, sinistral view. Scale-bars are in micrometres

\section{Remarks}

By having bicuspid deirids, Proyseria petterae n. sp. differs from its two congeners, $P$. decora and $P$. alcedonis (Puqin, Yanyin \& Guocal, 1991) n. comb., which possess tricuspid deirids. In addition, the male of the new species has collarette, each half of which is armed with 56 pointed cusps (Fig. 1A), while those of $P$. decora are 46-48 in number and rounded (Fig. 3B) (see below). P. alcedonis has a cuticular collar situated almost equidistantly between the posterior rim of the collarette and the deirids, as described by Puqin et al. (1991); a collar is absent in the new species.

\section{Proyseria decora (Dujardin, 1845) Petter, 1959}

Syns Dispharagus decorus Dujardin, 1845; Histiocephalus decorus (Dujardin, 1845) Diesing, 1854; Yseria decora (Dujardin, 1845) Gedoelst, 1919, Prionostemma decorum (Dujardin, 1845) Gendre, 1920; Streptocara decora (Dujardin, 1845) Skrjabin, 1916

Host: Alcedo atthis (L.) (Coraciiformes: Alcedinidae). Locality: Near the city of Chalus, Iran, October 1951. 
Site in host: Under the koilin lining of the gizzard. Intensity of infection: 3 males. Voucher material: MNHN 527A.

\section{Description (Fig. 3)}

Male $(\mathrm{n}=3$; except when otherwise indicated). Body 5.05-5.46 (5.17) mm long. Maximum body width 80-83 (82), posterior to oesophago-intestinal junction; body width at level of cloaca 54-58 (57). Tail 132-151(143) long. Cuticle 3-4 thick, with transverse striation slightly distinct, 5-6 apart. Collarette, in 2 halves, 22-26 long, $35(\mathrm{n}=1)$ wide in lateral view; each half bears $46-48$ rounded cusps on its entire rim (Fig. 3A, B). Deirids tricuspid (Fig. 3A, C), about 10 long, situated at 103-110 (106) from anterior extremity. Excretory pore located at 215-229 (223) from anterior body end. Buccal cavity 123-132 (128) long, 8-9 wide. Muscular oesophagus 500-585 (547) long, 25-26 wide at mid-length. Glandular oesophagus 1,360-1,461 (1,421) long, 42-45 (44) wide at mid-length. Nerve-ring at 148-157 (151) from anterior extremity. Caudal alae slightly developed, 248-279 (261) long (Fig. 3E). Precloacal papillae represented by single, ventral, precloacal papilla and 4 pairs of papillae: pairs 1, 3 and 4 subventral, pedunculate and arranged equidistantly, second pair of papillae lateral, situated at level of first pair. Postcloacal papillae 6 pairs: 5 subventral pedunculate pairs and 1 small, sessile pair, situated between bases of last pair of pedunculate papillae. Left spicule 261-282 (270) long, composed of handle $136(\mathrm{n}=1)$ long and blade 125 $(\mathrm{n}=1)$ long (Fig. 3E). Right spicule robust, 96-98 (97) long, armed with two prominent distal cusps (Fig. 3D). $\mathrm{I}_{\mathrm{mOE} / \mathrm{gOE}} 0.35-0.43$ (0.39); I $\mathrm{I}_{\mathrm{OE} / \mathrm{BL}} \quad 0.36-0.40$ (0.38); I LSP/RSP 2.69-2.94 (2.79).

\section{Remarks}

The present redescription is based on the male specimens studied by Chabaud (1953). This sample differs from the original description of $P$. decora mainly in its greater body dimensions and slightly longer spicules (Table 1). However, both samples have a similar morphology of the collarette and the position, size and shape of deirids.

Oshmarin (1963) did not provide morphometric data for the three males from A. atthis in the Russian Far East; however, the morphology of the anterior extremity illustrated by him resembles that of $P$. decora. The record of this species from Vietnam by Ryzhikov \& Khokhlova (1964) was complemented with a description published by Skrjabin et al. (1965). This material differs from the other three records in its collarette with a prominent denticulated posterior rim and deirids with three pointed cusps.

\section{Proyseria sp.}

Host: Alcedo euryzona Temminck (Coraciiformes: Alcedinidae).

Locality: Gombak Field Station, Selangor, Malaysia $\left(3^{\circ} 19^{\prime} 12^{\prime \prime} \mathrm{N}, 101^{\circ} 45^{\prime} 0^{\prime \prime} \mathrm{E}\right.$, altitude $\left.970 \mathrm{~m}\right)$.

Site in host: Under the koilin lining of the gizzard.

Prevalence and intensity of infection: 1 male found in 3 examined birds.

Voucher: MHNG-INVE-87385 (1 male).

\section{Description (Fig. 4)}

Male. Body $5.35 \mathrm{~mm}$ long. Maximum body width at level of oesophago-intestinal junction 116; body width at level of cloaca 55. Tail 166 long. Cuticle 4-5 thick, with transverse striations 5-6 apart. Collarette, formed by 2 halves, 32 long and 43 wide in lateral view; each half bears 57 cusps on its entire rim (Fig. 4A). Deirids tricuspid, 14-15 long, 17 wide, at 111 from anterior extremity. Left and right postdeirds 5 long (Fig. 4E), situated at 1,313 and 1,831, respectively, from posterior extremity. Cuticular collar 6 long, surrounds body at 70 from anterior extremity. Excretory pore at 250 from anterior extremity. Buccal cavity 151 long, 9 wide. Muscular oesophagus 649 long, 30 wide at midlength and 45 wide at its posterior end. Glandular oesophagus 1,482 long, with maximum width 96 situated at mid-length. Nerve-ring at 165 from anterior extremity. Testis reflection at $2.75 \mathrm{~mm}$ from anterior extremity. Caudal alae slightly developed, 301 long (Fig. 4B, C). Precloacal papillae represented by single ventral precloacal papilla and 4 pairs of pedunculate papillae: pairs1, 3 and 4 subventral, pair 2 displaced in lateral direction. Postcloacal papillae 6 pairs: 5 subventral pedunculate pairs and 1 small sessile pair, situated between bases of last pair of subventral papillae. Phasmids posterior to last pair of papillae. Left spicule 277 long, composed of handle 133 long and blade 144 long (Fig. 4B, C). Right spicule robust, 95 long, with 2 prominent distal cusps (Fig. 4D). 


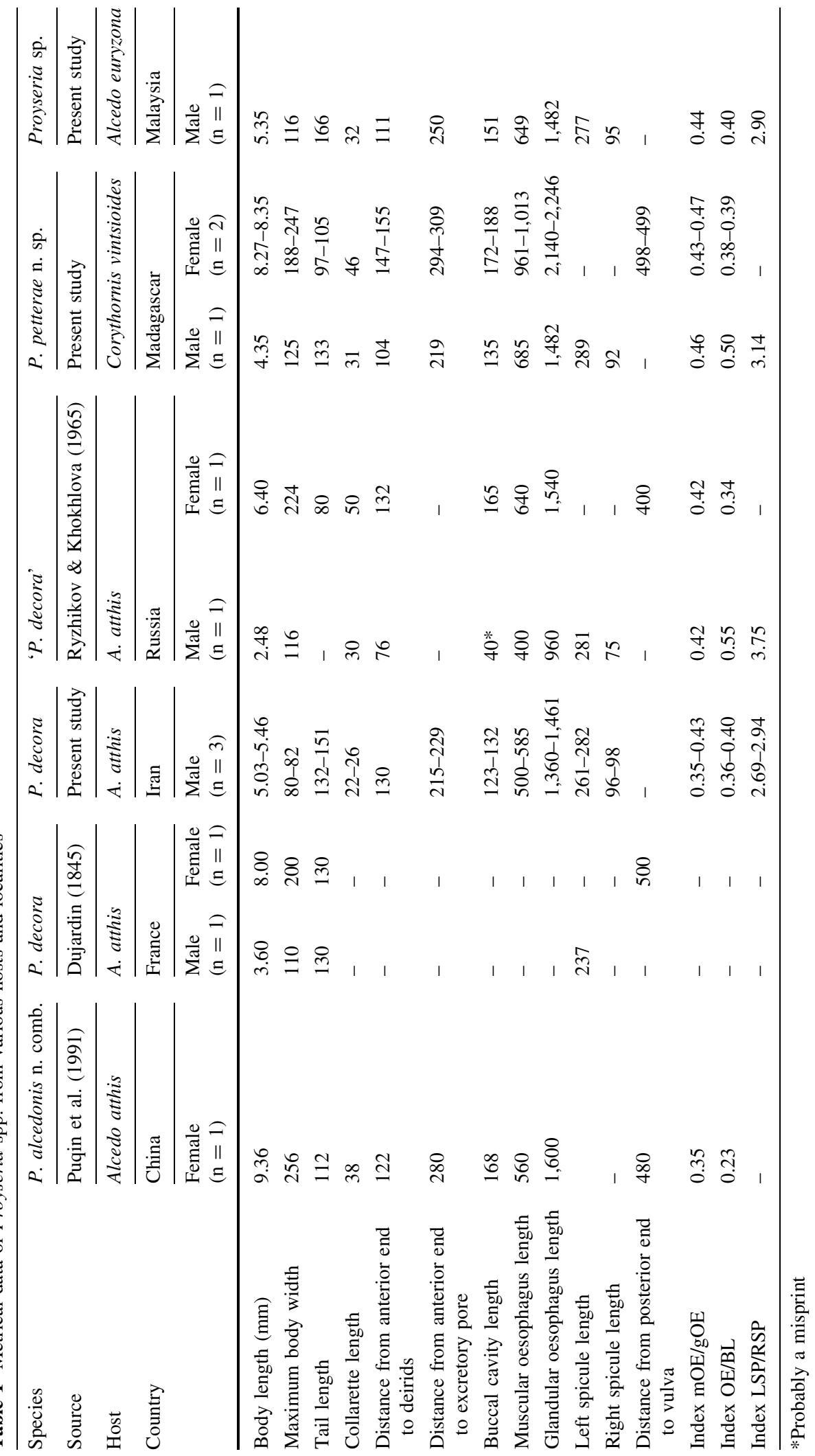




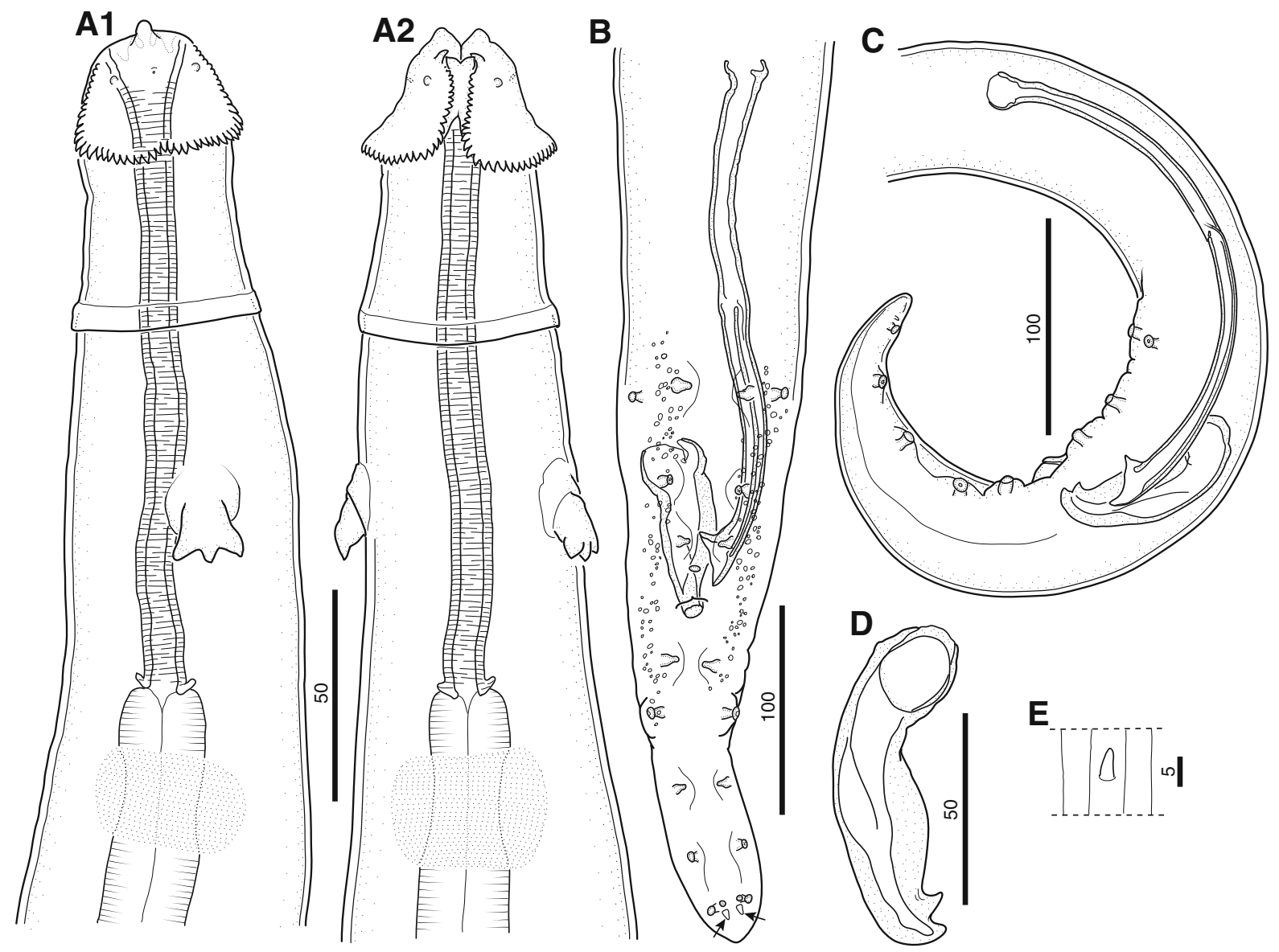

Fig. 4 Proyseria sp. (male) from Alcedo euryzona, Malaysia. A, Anterior end, lateral (A1) and dorsoventral (A2) view; B, Posterior end, ventral view, note phasmids (arrows); C, Posterior end, sinistral view; D, Right spicule, dextral view; E, Postdeirid. Scale-bars are in micrometres

Remarks

The male described above from A. euryozona corresponds in its morphology of the anterior body end, spicules and arrangement of the caudal papillae to other known males of Proyseria. In addition, by having a cuticular collar situated at the oesophageal region, this specimen resembles $P$. alcedonis (Puqin, Yanyin \& Guocal, 1991) n. comb. (see Puqin et al., 1991). The latter was described from a single female collected from A. atthis in China and its male remains unknown. Therefore, a more precise comparison between these two samples is impossible. Nevertheless, the male individual described here complements our knowledge of the morphological diversity of the genus.

\section{Discussion}

Until now, ten species have been assigned to the genus Stegophorus Wehr, 1934 (see below). With the exception of Stegophorus alcedonis Puqin, Yanyin \& Guocal, 1991, a parasite of the common kingfisher Alcedo atthis, all other members of Stegophorus are parasites of seabirds of the orders Procellariiformes, Charadriiformes and Sphenisciformes. Stegophorus alcedonis, as described by Puqin et al. (1991), corresponds to the genus Proyseria with its collarette bearing cusps on the entire rim (including its anterior parts) and a vulva situated near the posterior extremity of the body. It differs from other Stegophorus spp. characterised by a collarette bearing cusps on the posterior part of their rim only and a vulva situated 
near the mid-body. Therefore, we transfer this species to the genus Proyseria as P. alcedonis (Puqin, Yanyin \& Guocal, 1991) n. comb.

Currently, the genus Proyseria consists of three nominal species parasitic in kingfishers: $P$. decora from Alcedo atthis recorded throughout the Palaearctic Region, $P$. alcedonis from $A$. atthis in China and $P$. petterae n. sp. from Corythornis vintsioides in Madagascar. The male specimen identified here as Proyseria sp. is probably conspecific with $P$. alcedonis, whose males remain unknown. In addition, the sample of $P$. decora from Vietnam, described by Ryzhikov \& Khokhlova (1964), differs from the original description of the species (see comments above). The members of Proyseria are relatively uniform in the morphology of the left and right spicules, the arrangement of caudal papillae in males, the position of the vulva and the lengths of the muscular and glandular portions of the oesophagus (see Table 1). However, they can be easily distinguished by the morphology of the collarette and deirids as well as by the presence or absence of an additional cuticular collar. The small number of published records of Proyseria spp. as well as the low levels of intensity of infection (up to three specimens) characterise this acuariid genus as rare.

In view of the present morphological studies, we propose the following amended diagnosis of the genus Proyseria:

Small acuariid nematodes. Anterior end with two pseudolabia, each bearing single amphid and one pair of papillae. Anterior cuticular ornamentation in form of collarette, consisting of two lateral halves, with numerous teeth along their entire rims. Pseudolabia between two parts of collarette fused into single structure. Deirids large, with two or three cusps, situated anteriorly to nerve-ring. Excretory pore posterior to nerve-ring. Buccal cavity long, with conspicuous cross-striations. Muscular and glandular regions of oesophagus distinct. Phasmids subterminal. Male: with narrow caudal alae; precloacal pairs of papillae composed of single ventral sessile papilla and four pairs of papillae: pairs 1, 3 and 4 subventral and pedunculate, pair 2 sublateral; postcloacal papillae consisting of five pairs of pedunculate papillae and one pair of sessile papillae situated at the bases of pedunculate pairs of papillae; area rugosa absent, left spicule long, consisting of handle and blade; right spicule short and robust, armed by two prominent cusps. Female: vulva posterior; vagina vera short, separated from short, muscular vagina uterina by well-developed circular musculature. Monodelphic. Under koilin lining of muscular stomach of the Alcedinidae (Coraciiformes). Type-species $P$. decora (Dujardin, 1845). Other species: $P$. petterae and $P$. alcedonis.

Wehr (1934) erected the genus Stegophorus to accommodate Stegophorus stellaepolaris (Parona, 1901). Later, Johnston \& Mawson (1945) recognised Paryseria Johnston, 1937 as a junior synonym of Stegophorus. Skrjabin et al. (1965) reasonably corrected the generic definition specifying that the collarette of Proyseria is composed of two lateral parts instead of being a single structure surrounding the head region as stated by Wehr (1934).

The members of Stegophorus can be distinguished from those of Proyseria by their collarette bearing cusps on the posterior part of the rim, well-developed caudal alae in males, four pairs of subventral precloacal papillae, vulva situated at mid-body or slightly posteriorly, long ovejector and a didelphic female reproductive system.

Currently, the genus Stegophorus includes the following species:

- Stegophorus stellaepolaris (Parona, 1901) Wehr, 1934 [Syns Histiocephalus stellaepolaris Parona, 1901; Streptocara stellaepolaris (Parona, 1901) Skrjabin, 1916; Yseria stellaepolaris (Parona, 1901) Gedoelst, 1919] described from Fulmarus glacialis (L.) (type-host) in the Arctic (Parona, 1901). Subsequently, this species has been reported from diverse fish-eating seabirds of the orders Procellariiformes (Hydrobatidae, Procellariidae) and Charadriiformes (Alcidae, Laridae), mainly from the Arctic and sub-Arctic, e.g. F. glacialis from the North Sea and Hydrobates pelagicus (L.) in England (Baylis, 1928); Uria lomvia (L.) in the Greenland Sea and $F$. glacialis from the northern North Atlantic (Wehr, 1934); $F$. glacialis in Greenland (Baer, 1956); F. glacialis in the USA (Dunn, 1962); Synthliboramphus antiquus (Gmelin) in the USA (Schmidt, 1964); Larus crassirostris Vieillot and $U$. lomvia from the Peter the Great Gulf, Sea of Japan (Smetanina, 1981); Stercorarius longicaudus Vieillot and Larus argentatus Pontoppidan from the lower Yenisei River (Sergeeva, 1969); Larus canus L. and 
Hydrobates pelagicus (L.) in Norway (Bakke \& Barus, 1976a, b); L. crassirostris and Uria aalge (Pontoppidan) in the Rimsky-Korsakov Archipelago (Alekseev \& Smetanina, 1968); Alle alle (L.), Alca torda $\mathrm{L}$. and $U$. aalge near Newfoundland (Threlfall, 1971); Puffinus gravis (O'Reilly) in the USA (Foster et al., 1996); Larus hyperboreus Gunnerus in the Svalbard Archipelago (Sagerup et al., 2000); U. aalge and U. lomvia from the North Atlantic (Muzaffar, 2009).

- Stegophorus adeliae (Johnston, 1938) Johnston \& Mawson, 1945 (Syn. Paryseria adeliae Johnston, 1938) from Pygoscelis adeliae (Hombron \& Jacquinot) (Sphenisciformes: Spheniscidae) (type-host) in Commonwealth Bay, Antarctica (Johnston, 1938); Pygoscelis papua (J. R. Forster) on the Antarctic Peninsula (González-Acuña et al., 2013).

- Stegophorus diomedeae (Johnston \& Mawson, 1942) Johnston \& Mawson, 1945 from Diomedea exulans L. (Procellariiformes: Diomedeidae) (type-host) and Thalassarche melanophris (Temminck) (=Diomedea melanophris Temminck) (Procellariiformes: Diomedeidae), Thalassarche chrysostoma (J. R. Forster) (=Diomedea chrysostoma J. R. Forster) in Australia (Johnston \& Mawson, 1942a, 1952); T. melanophris in Brazil (Rodrigues \& Mendonça, 1967); Puffinus gravis (O'Reilly) in the USA (Foster et al., 1996).

- Stegophorus pachyptilae (Johnston \& Mawson, 1942) Johnston \& Mawson, 1945 from Pachyptila vittata (G. Forster) (type-host) (Procellariiformes: Diomedeidae) and Pachyptila desolata (Gmelin) in Australia (Johnston \& Mawson, 1942a, b).

- Stegophorus macronectes (Johnston \& Mawson, 1942) Johnston \& Mawson, 1945 from Macronectes giganteus (Gmelin) (Procellariiformes: Procellariidae) (type-host) and Thalassarche chrysostoma in Australia (Johnston \& Mawson, 1942a); M. giganteus, Stercorarius antarcticus lonnbergi (Mathews) (=Stercorarius skua loennbergi) and Chionis albus (Gmelin) (Charadriiformes: Chionidae) on King George Island (Zdzitowiecki \& Dróżdż, 1980); P. adeliae in Atka Bay, Antarctica (Plötz, 1983); Pygoscelis antarctica (Forster) on Deception Island (Vidal et al., 2012); P. papua on King George Island (Diaz et al., 2013).

- Stegophorus paradeliae Johnston \& Mawson, 1945 from Pygoscelis adeliae (type-host) in
Commonwealth Bay, Antarctica (Johnston \& Mawson, 1945); P. papua, Eudyptes chrysocome (J. R. Forster) [=Eudyptes cristatus (Miller)] and Eudyptes chrysolophus (Brandt) on Heard Island, Australia (Mawson, 1953). Zdzitowiecki \& Dróżdż (1980) considered this species as a synonym of $S$. macronectes.

- Stegophorus heardi Mawson, 1953 from Oceanites oceanicus (Kuhl) (Procellariiformes: Hydrobatidae) (type-host) and Pelecanoides georgicus Murphy \& Harper (Procellariiformes: Hydrobatidae) on Heard Island (Australia) (Mawson, 1953).

- Stegophorus arctowskii Zdzitowiecki \& Dróżdż, 1980 from S. antarcticus lonnbergi (Mathews) [=Stercorarius skua loennbergi (Mathews)] (Charadriiformes: Stercorariidae) (type-host) and $M$. gigantheus on King George Island (Zdzitowiecki \& Dróżdż, 1980).

- Stegophorus stercorarii Leonov, Sergeeva \& Tsimbalyuk, 1966 from S. longicaudus (Charadriiformes: Stercorariidae) (type-host), Fratercula cirrhata (Charadriiformes: Alcidae), Fratercula cirrhata (Pallas) and Aethia cristatella (Pallas) (Charadriiformes: Alcidae) on the Chukotka Peninsula, Fulmarus glacialis (L.) on the Commandor Islands and $S$. longicaudatus from the lower Yenisey River (Leonov et al., 1966); Aethia pusilla (Pallas) (Charadriiformes: Alcidae) in the Peter the Great Gulf, Sea of Japan (Smetanina, 1981) and in the Rimsky-Korsakov Archipelago (Alekseev \& Smetanina, 1968); $S$. longicaudus and Stercorarius pomarinus Temminck from the lower Yenisey River (Sergeeva, 1969); Synthliboramphus antiquus (Gmelin) in Japan (Yokohata, 2003); Puffinus tenuirostris (Temminck) in Japan (Iwaki et al., 2012).

Despite of the numerous records of Stegophorus spp., the morphology of the majority of its species is known mainly from their brief original descriptions and further studies are needed.

More than 250 species classified in 45 genera within the family Acuariidae are known (Mutafchiev $\&$ Kinsella, 2012; Bain et al., 2014). Among these, the genera Aviculariella Wehr, 1931 (of the subfamily Acuariinae Railliet, Henry \& Sisoff, 1912) and Proyseria Petter, 1959 (of the subfamily Seuratiinae Chitwood \& Wehr, 1932), containing six and three species, respectively, are specific parasites of kingfishers (Mutafchiev et al., 2009; present study). 
Kingfishers are also hosts of six out of the eight valid species of Quasithelazia Maplestone, 1932 (the subfamily Schistorophinae Travassos, 1918) (see Mutafchiev et al., 2014), one species of Skrjabinoclava Sobolev, 1964 (Acuariinae), one of Ancyracanthopsis Diesing, 1861 (Schistorophinae) and one of Sobolevicephalus Parukhin, 1964 (Schistorophinae) (see Wong \& Anderson, 1983; Wong \& Lankester, $1985 \mathrm{a}, \mathrm{b})$. In addition, two immature specimens of Skrjabinocerca prima Shikhobalova, 1930 (Acuariinae), usually parasitising chradriiform birds, were reported from Halcyon pileata (Boddaert) in the Rimsky-Korsakov Archipelago (Alekseev \& Smetanina, 1968).

Acknowledgments This study was supported by the SciexHMS $^{\text {ch }}$ Program CRUS, Switzerland. The re-examination of the voucher material of Proyseria decora was possible due to a SYNTHESYS 2 (EC FP7) grant FR-TAF-841 to the senior author, kindly hosted by Dr O. Bain. We are grateful to Prof. Rosli Hashim and Prof. Rosli Ramli, Institute of Biological Sciences, University of Malaya, Kuala Lumpur, for their kind assistance in the organisation of the field studies and for making available facilities at the Gombak Biological Station. We thank Dr Jeanne Rasamy (University of Antananarivo), Dr Steven M. Goodman, Dr Marie Jeanne Raherilalao (Vahatra Foundation) and biologists Ms Lalatiana Odile Randriamiharisoa, Ms Ranja Andriantsoa and Mr Tantely Hasina Dimbiniaina Razafiarisolo for their assistance to organise and carry out field studies in Madagascar. The field trips of JM and BBG in Malaysia and Madagascar were in the frame of a project funded by the National Science Foundation, USA (PBI awards no. 0818696 to Prof. Janine N. Caira and no. 0818823 to Prof. Kirsten Jensen). We are thankful to Mr Emmanuel Tardy (MHNG) for his assistance with the SEM studies.

\section{References}

Alekseev, V. M., \& Smetanina, Z. B. (1968). Nematodes of fisheating birds of Rimsky-Korsakov Archipelago. In: Skrjabin, K. I. \& Mamaev, Y. L. (Eds) Gel'minty Zhivotnykh Tikhogo Okeana. Moscow: Nauka, pp. 97-104 (In Russian).

Baer, J. G. (1956). Parasitic helminths collected in West Greenland. Meddelelser Om Grønland, 124, 1-55.

Bain, O., Mutafchiev, Y., \& Junker, K. (2014). Order Spirurida. In: Schmidt-Rhaesa, A. (Ed.) Handbook of Zoology. Volume 2. Nematoda. Berlin: De Gruyter, pp. 661-732.

Bakke, T. A., \& Barus, V. (1976a). Studies of the helminth fauna of Norway XXXVII: The common gull, Larus canus L., as final host for Nematoda. II. Qualitative and quantitative data on species of Acuariidae, Capillariidae, Strongyloididae, Syngamidae and Tetrameridae; with notes on hostparasite relationship. Norwegian Journal of Zoology, 24, 7-31.
Bakke, T. A., \& Barus, V. (1976b). Studies of the helminth fauna of Norway XXXIX: Nematodes from Hydrobates pelagicus L. and Rissa tridactyla L. (Aves) in Norway. Norwegian Journal of Zoology, 24, 185-189.

Baylis, H. A. (1928). Records of some parasitic worms from British vertebrates. Annals and Magazine of Natural History, Ser., 10, 1, 329-343.

Casiraghi, M., Anderson, T. J. C., Bandi, C., Bazzocchi, C., \& Genchi, C. (2001). A phylogenetic analysis of filarial nematodes: comparison with the phylogeny of Wolbachia endosymbionts. Parasitology, 122, 93-103.

Chabaud, A. G. (1953). Sur un nématode Acuariidae, parasite du martin-pêcheur Alcedo atthis L. Annales de Parasitologie Humaine et Comparée, 28, 365-371.

Diaz, J. I., Fusaro, B., Longarzo, L., Coria, N. R., Vidal, V., Jerez, S., Ortiz, J., \& Barbosa, A. (2013). Gastrointestinal helminths of Gentoo penguins (Pygoscelis papua) from Stranger Point, 25 de Mayo/King George Island, Antarctica. Parasitology Research, 112, 1877-1881.

Dujardin, F. (1845). Histoire naturelle des helminthes ou vers intestinaux. Paris: Librairie Encyclopédique de Roret, 654 pp.

Dunn, F. L. (1962). Stegophorus stellae-pollaris (Acuariidae: Nematoda) in the Pacific Fulmar. The Auk, 79, 275-276.

Foster, G. W., Kinsella, J. M., Price, R. D. F., Mertins, J. W., \& Forrester, D. J. (1996). Parasitic helminths and arthropods of greater shearwaters (Puffinus gravis) from Florida. Journal of the Helminthological Society of Washington, 63, 83-88.

González-Acuña, D., Hernández, J., Moreno, L., Herrmann, B., Palma, R., Latorre, A., Medina-Vogel, G., Kinsella, J. M., Martín, N., Araya, K., Torres, I., Fernandez, N., \& Olsen, B. (2013). Health evaluation of wild gentoo penguins (Pygoscelis papua) in the Antarctic Peninsula. Polar Biology, 36, 1749-1760.

Iwaki, T., Kato, C., \& Kurose, N. (2012). Parasitic helminthes of wild birds in Kanagawa Prefecture, Japan. Japanese Journal of Zoo and Wildlife Medicine, 17, 119-126 (In Japanese).

Johnston, H. T. (1938). Australasian Antarctic Expedition 1911-14. Series C. Vol. X, Part 5. Parasitic Nematoda. Sydney: William Applegate Gullick, $31 \mathrm{pp}$.

Johnston, H. T., \& Mawson, P. M. (1942a). Nematodes from Australian albatrosses and petrels. Transactions of the Royal Society of South Australia, 66, 66-70.

Johnston, H. T., \& Mawson, P. M. (1942b). Remarks on some parasitic nematodes. Records of the South Australian Museum, 7, 183-186.

Johnston, H. T., \& Mawson, P. M. (1945). Parasitic nematodes. Reports of the British, Australian and New Zealand Antarctic Research Expedition 1929-1931. Reports. Ser. B, 5, 73-160.

Johnston, H. T., \& Mawson, P. M. (1952). Some nematodes from Australian birds and mammals. Transactions of the Royal Society of South Australia, 75, 30-37.

Leonov, V. A., Sergeeva, T. P., \& Tsimbalyuk, A. K. (1966). A new nematode - Stegophorus stercorarii n. sp. (Nematoda: Acuariidae). Trudy Gel'mintologicheskoy Laboratorii Akademii Nauk SSSR, 17, 91-94 (In Russian).

Mawson, P. M. (1953). Parasitic Nematoda collected by the Australian National Antarctic Research Expedition: Heard 
Island and Macquarie Island, 1948-1951. Parasitology, 43, 291-297.

Mutafchiev, Y., \& Kinsella, J. M. (2012). Redescription of Chabaudacuaria multispinosa (Pérez Vigueras, 1938) n. g., n. comb. (Nematoda: Spirurida: Acuariidae) based on specimens from Ardea herodias L. and Nyctanassa violacea (L.) (Ardeidae) in Florida. Systematic Parasitology, 83, 85-93.

Mutafchiev, Y., Mariaux, J., \& Georgiev, B. B. (2014). Two new species of Quasithelazia Maplestone, 1932 (Nematoda: Acuariidae) from Malaysia, with an amended diagnosis and review of the genus. Systematic Parasitology, 88, 103-117.

Mutafchiev, Y., Zehtindjiev, P., \& Georgiev, B. B. (2009). First record of the nematode Aviculariella alcedonis (Yamaguti \& Mitunaga, 1943) (Spirurida, Acuariidae) in Europe, with SEM observations and comments on its taxonomic position. Acta Parasitologica, 54, 374-379.

Muzaffar, S. B. (2009). Helminths of murres (Alcidae: Uria spp.): markers of ecological change in the marine environment. Journal of Wildlife Diseases, 45, 672-683.

Oshmarin, R. G. (1963). Helminths of mammals and birds in the Primorsk region. Moscow: Izdatel'stvo Akademii Nauk SSSR, 323 pp (In Russian).

Parona, C. (1901). Diagnosi di una nuova specie di nematode, Histiocephalus stellae-polaris n. sp. Bollettino dei Musei di Zoologia ed Anatomia Comparata della Reale Università di Torino, 16, pp. 1.

Petter, A. J. (1959). Redescription de Paryseria adeliae Johnston, 1938. Remarques sur le genre Paryseria et les genres voisins Rusguniella, Aviculariella, Proyseria gen. nov. et Seuratia. Annales de Parasitologie Humaine et Comparée, 34, 322-330.

Plötz, J. (1983). Entwicklungsbiologie und Ökologie der Parasiten von Robben und Seevögeln. Berichte zur Polarforschung, 13, 27-29.

Puqin, W., Yanyin, W., \& Guocal, H. (1991). Notes on some Acuarioidea of birds from Fujian, China. Journal of Fujian Normal University, Natural Science, 7, 86-91 (In Chinese).

Rodrigues, H. O., \& Mendonça, J. M. (1967). Redescrição de Stegophorus diomedeae (Johnston \& Mawson, 1942) Johnston \& Mawson, 1945 (Nematoda, Spiruroidea). Memórias do Instituto Oswaldo Cruz, 65, 149-152.

Ryzhikov, K. M., \& Khokhlova, I. G. (1964). Contribution to the knowledge of nematodes of birds in Vietnam. Materialy $k$ Nauchnoy Konferencii Vsesouyuznogo Obshtestva Gel'mintologov, 2, 116-118 (In Russian).

Sagerup, K., Henriksen, E. O., Skorping, A., Skaare, J. U., \& Gabrielsen, G. W. (2000). Intensity of parasitic nematodes increases with organochlorine levels in the glaucous gull. Journal of Applied Ecology, 37, 532-539.
Schmidt, G. D. (1964). First report of Stegophorus stellaepolaris (Parona, 1901) Wehr, 1934 (Nematoda: Ancyracanthidae) from North America. Canadian Journal of Zoology, 42, 1157.

Sergeeva, T. P. (1969). Nematode fauna of gulls in the USSR. Trudy Gel'mintologicheskoy Laboratorii Akademii Nauk SSSR, 20, 146-155 (In Russian).

Skrjabin, K. I., Sobolev, A. A., \& Ivashkin, V. M. (1965). [Spirurata of animals and man and the diseases caused by them. Part 3. Acuarioidea]. In: Skrjabin, K. I. (Ed.) Osnovy Nematologii, Vol. 14. Moscow: Nauka, 572 pp (In Russian).

Smetanina, Z. B. (1981). Helminths of marine fish-eating birds of Peter the Great Bay. In: Mamaev, Y. L. (Ed.) Biologiya $i$ Sistematika Gel'mintov Zhivotnykh Daln'nego Vostoka. Vladivostok: Izdatel'stvo Akademii Nauk SSSR, pp. 71-81 (In Russian)

Threlfall, W. (1971). Helminth parasites of alcids in the northwestern North Atlantic. Canadian Journal of Zoology, 49, $461-466$.

Vidal, V., Ortiz, J., Diaz, J. I., Ybañez, M. R. R., Amat, M. T., Palacios, M. J., Benzal, J. Valera, F., Cruz, C., Motas, M., \& Barbosa, A. (2012). Gastrointestinal parasites in chinstrap penguins from Deception Island, South Shetlands, Antarctica. Parasitology Research, 111, 723-727.

Wehr, E. E. (1934). Descriptions of three bird nematodes, including a new genus and a new species. Journal of the Washington Academy of Sciences, 24, 341-347.

Wong, P. L., \& Anderson, R. A. (1983). Revision of the genera Cordonema Schmidt and Kuntz, 1972 and Skrjabinoclava Sobolev, 1943 (Nematoda: Acuarioidea). Canadian Journal of Zoology, 61, 339-348.

Wong, P. L., \& Lankester, M. W. (1985a). Revision of the genus Ancyracanthopsis Diesing, 1861 and description of a new genus Molinacuaria n. gen. (Nematoda: Acuarioidea). Canadian Journal of Zoology, 63, 1556-1564.

Wong, P. L., \& Lankester, M. W. (1985b). Revision of the genus Sobolevicephalus Parukhin, 1964 (Nematoda: Acuarioidea). Canadian Journal of Zoology, 63, 1576-1581.

Yokohata, Y. (2003). Review on the parasitic helminths obtained from five seabird species killed in "Nakhodka" oil spill with some related informations. In: Tazaki, K. (Ed.) Heavy oil spilled from Russian tanker "Nakhodka" in 1997: towards eco-responsibility, earth sense. Kanazawa: Kanazawa University Press, pp. 138-156

Zdzitowiecki, K., \& Dróżdż, J. (1980). Redescription of Stegophorus macronectes (Johnston et Mawson, 1942) and description of Stegophorus arctowskii sp. n. (Nematoda, Spirurida) from birds of South Shetlands (the Antarctic). Acta Parasitologica Polonica, 27, 205-212. 